\title{
Correction to: Treatment of metabolic acidosis with sodium bicarbonate delays progression of chronic kidney disease: the UBI Study
}

\author{
Biagio R. Di lorio ${ }^{1,12}$ - Antonio Bellasi ${ }^{2} \cdot$ Kalani L. Raphael ${ }^{3} \cdot$ Domenico Santoro $^{4} \cdot$ Filippo Aucella $^{5}$. \\ Luciano Garofano $^{6} \cdot$ Michele Ceccarelli $^{6,7} \cdot$ Luca Di Lullo $^{8}$. Giovanna Capolongo ${ }^{9}$. Mattia Di lorio ${ }^{10}$. \\ Pasquale Guastaferro ${ }^{11}$. Giovambattista Capasso ${ }^{9}$ on behalf of The UBI Study Group
}

Published online: 7 May 2020

(c) The Author(s) 2020

\section{Correction to: Journal of Nephrology (2019) 32:989-1001 https://doi.org/10.1007/s40620-019-00656-5}

It occurred to us that a simple but significant calculation error was made in Table 2 in the dose of bicarbonate administered. Indeed, contrary to what reported in Table 2, the dose of sodium bicarbonate administered during study was:

Mean (SD) SB administered dose ( $\mathrm{mmol} / \mathrm{kg}$ bw/day)

\begin{tabular}{lllll}
\hline & Baseline & 1 year & 2 year & 3 year \\
\hline SC & - & $0.14(0.12)$ & $0.12(0.03)$ & $0.11(0.03)$ \\
SB & - & $0.56(0.05)$ & $0.55(0.05)$ & $0.54(0.06)$ \\
\hline
\end{tabular}

We sincerely apologize for the inconvenience. The updated Table 2 has been copied below:

The original article can be found online at https://doi.org/10.1007/ s40620-019-00656-5.

Biagio R. Di Iorio

br.diiorio@gmail.com

1 Nephrology and Dialysis Unit, PO “A. Landolfi”, Solofra, Avellino, Italy

2 Department of Research, Innovation, Brand Reputation, Bergamo Hospital, ASST Papa Giovanni XXIII, Bergamo, Italy

3 Division of Nephrology and Hypertension, Department of Internal Medicine, University of Utah Health, Salt Lake City, UT, USA

4 Dialysis and Nephrology Unit, University of Messina, Messina, Italy

5 Department of Nephrology and Dialysis, IRCCS "Casa Sollievo della Sofferenza”, San Giovanni Rotondo, Foggia, Italy
6 Biogem, Section of Genetic and Translational Medicine, Ariano Irpino, Avellino, Italy

7 Department of Science and Technology, University of Sannio, Benevento, Italy

8 Department of Nephrology and Dialysis, "L. Parodi-Delfino" Hospital, Colleferro, Roma, Italy

9 Department of Translational Medical Sciences, University of Campania "Luigi Vanvitelli”, Naples, Italy

10 Data Scientist, Landolfi Nephrology Dialysis Consultant, Solofra, Avellino, Italy

11 Department of Nephrology, "G. Criscuoli” Hospital, Sant'Angelo dei Lombardi, Avellino, Italia

12 Nephrology and Dialysis, "Antonio Cardarelli" hospital, Naples, Italia 
Table 2 Mean (SD) dose of sodium bicarbonate administered and mean (SD) and range (min-max) of serum bicarbonate $(\mathrm{mmol} / \mathrm{l})$ during the study according to study arm allocation

\begin{tabular}{lllll}
\hline & Baseline & $1^{\mathrm{b}}$ year & $2^{\mathrm{b}}$ year & $3^{\mathrm{b}}$ year \\
\hline Standard care (SC) & - & $0.14(0.12)$ & $0.12(0.03)$ & $0.11(0.03)$ \\
Mean (SD) SB administered dose (mmol/kg-bw/day) & - & $0.28(0.23)^{\mathrm{a}}$ & $0.24(0.05)^{\mathrm{b}}$ & $0.21(0.06)^{\mathrm{c}}$ \\
Mean serum levels of bicarbonate (SD) (mmol/l) & $21.4(2.1)$ & $22.3(1.9)$ & $21.9(1.3)$ & $21.9(1.9)$ \\
Range of serum bicarbonate (min-max) (mmol/l) & $16-25$ & $17-26$ & $18-26$ & $17-26$ \\
Sodium bicarbonate (SB) & - & $0.56(0.05)$ & $0.55(0.05)$ & $0.54(0.06)$ \\
Mean (SD) SB administered dose (mmol/kg-bw/day) & - & $1.13(0.10)$ & $1.12(0.11)$ & $1.09(0.12)$ \\
Mean serum levels of bicarbonate (SD) (mmol/l) & $21.5(2.4)$ & $25.0(2.4)$ & $26.0(2.4)$ & $26.1(1.7)$ \\
Range of serum bicarbonate (min-max) (mmol/l) & $13-26$ & $20-29$ & $21-30$ & $22-30$ \\
P value between group comparison & 0.006 & $<0.001$ & $<0.001$ & $<0.001$
\end{tabular}

a78 patients treated for $2-4$ months during the first year

b 26 patients treated for 3-5 months during second year

c 33 patients treated for $2-4$ months during third year
Open Access This article is licensed under a Creative Commons Attribution 4.0 International License, which permits use, sharing, adaptation, distribution and reproduction in any medium or format, as long as you give appropriate credit to the original author(s) and the source, provide a link to the Creative Commons licence, and indicate if changes were made. The images or other third party material in this article are included in the article's Creative Commons licence, unless indicated otherwise in a credit line to the material. If material is not included in the article's Creative Commons licence and your intended use is not permitted by statutory regulation or exceeds the permitted use, you will need to obtain permission directly from the copyright holder. To view a copy of this licence, visit http://creativecommons.org/licenses/by/4.0/.

Publisher's Note Springer Nature remains neutral with regard to jurisdictional claims in published maps and institutional affiliations. 